\title{
Electrochemical Preparation of an Au Oxide Electrode and Its Application to Electro-Oxidation of Heterocycles Thiazole
}

\section{Lai-Hao WANG* and Kai-Bo JHANG}

\author{
Department of Medical Chemistry, Chia Nan University of Pharmacy and Science, \\ 60 Erh-Jen Road, Section 1, Jen Te, Tainan 71743, Taiwan
}

\section{* Corresponding author: e201466wang@msa.hinet.net}

\begin{abstract}
The growth and properties of $\mathrm{Au}$ oxide films formed on an $\mathrm{Au}$ electrode in a $0.1-1.0 \mathrm{M} \mathrm{NaOH}$ solution were investigated using potentiostatic and cyclic voltammetric techniques. Scanning electron microscopy images showed the structure of an Au oxide film on an Au electrode at various oxidation potentials: 1.5, 2.0, 2.5, and 3.0 V. The Au oxide electrode was used to determine oxidation potential of heterocycles thiazole in phosphate buffer $(\mathrm{pH} 2.21)$. The potential peaked at $0.54 \mathrm{~V}$ for rhodanine, $0.40 \mathrm{~V}$ for thiazolidine-2,4-dione, $0.47 \mathrm{~V}$ for thiazolidine, and $0.48 \mathrm{~V}$ for $\mathrm{L}(-)$-thiazolidine-4-carboxylic acid. Compared with the results obtained from an Au oxide electrode, the peak potential of heterocycles thiazole was less positive and the peak current 3-15 times higher than that of the peak potential found using a bare gold electrode.
\end{abstract}

(C) The Electrochemical Society of Japan, All rights reserved.

Keywords : Electro-Synthesis, Au Oxide Electrode, Heterocycles Thiazole

\section{Introduction}

Heterocycles thiazole is a heterocyclic compound with fivemembered rings containing nitrogen and sulfur; it has some biological and clinical significance. Thiazolidine-2,4-dione and 2thioxo-4-thiazolidinone (rhodanine) derivatives, for example, appear in many drugs that have therapeutic potential for managing longterm diabetes complications. ${ }^{1-6}$ In addition, they are found in antiinflammatory, ${ }^{7,8}$ antimicrobial, ${ }^{9,10}$ and antiviral drugs. ${ }^{11}$ Rhodanine and substituted rhodanines have been extensively investigated by organic chemists because of their close association with various types of biological activities. They are also of particular interest because they are used as highly sensitive spectrophotometric reagents (complexing agents) for analyzing ions..$^{12-15}$

Metal oxide materials with microstructures or nanostructures are extensively used for anticorrosion coatings, electrochemical capacitors, electronic parts, magnetic nanostructures, photochemical energy conversion, lithium-ion batteries, and display technology. ${ }^{16}$ The microscale/nanoscale effects in the catalytic properties of gold particles are well-known to be chemically inert. Recently, some studies $^{17-19}$ reported that the presence of oxidized Au species in the catalyst contributed to increased activity. The anodic oxidation of $\mathrm{Au}$ causes several types of $\mathrm{Au}$ oxide layers to form on electrode surfaces. There are studies of oxide growth on Au electrodes in alkaline and sulfuric acid solutions. ${ }^{20,21}$ The polarographic and electrolytic reduction of $\mathrm{L}(-)$-thiazolidine-4-carboxylic acid ${ }^{22-24}$ and rhodanine derivatives ${ }^{25,26}$ in acetate and phosphate buffer at pHs from 3.8 to 8.0 were investigated using a dropping mercury electrode (DME) and a mercury pool, respectively. Electrochemical studies (cyclic voltammetry, impedance spectroscopy) were done of the synthesized complexes of thiazolidine-2,4-dione with $\delta$ and $\pi$ acceptors. ${ }^{27}$ Although the DME offers greater specificity, it is limited because mercury is highly toxic and causes environmental problems. One paper ${ }^{28}$ dealing with the oxidation of thiazolidine-4carboxylic acid on platinum and gold electrodes using chronopotentiometry and voltammetry does not describe the other thiazole heterocycles. Little attention has been paid to the electrochemical measurements of thiazole heterocycles. Our paper refers to the electrochemical behavior of four 2,4-substituted derivatives of thiazolidine in various buffer solutions, and to the preparation of a $\mathrm{Au}$ oxide film on an $\mathrm{Au}$ electrode and then using it as a modified electrode to analyze the catalytic properties of heterocycles thiazole.

\section{Experimental}

\subsection{Apparatus and materials}

The electrolyte cell was designed with the following electrodes: a saturated calomel reference electrode (SCE), a stainless steel auxiliary electrode, and a gold (i.d.: $3 \mathrm{~mm}$ ) working electrode, and operated using a potentiostat/galvanostat (263A; EG\&G Princeton Applied Research, Princeton, NJ, USA)-controlled potentiostat. Cyclic and differential pulse voltammetric experiments were done using an electrochemical trace analyzer (Model 394; EG\&G Princeton Applied Research, Princeton, NJ). The heterocycles thiazole (Scheme 1) were tested with rhodanine, thiazolidine2,4-dione, thiazolidine (Acros Organics, Thermo Fisher Scientific, Geel, Belgium), and L(-)-thiazolidine-4-carboxylic acid (Alfa Aesar, Heysham, Lancashire, UK). Gold oxide was synthesized in our laboratory. All other reagents were locally purchased and of analytical grade.

\subsection{Procedures}

\subsubsection{Au oxide growth in alkaline solutions}

The $\mathrm{Au}$ oxide films for voltammetric measurements were electrochemically prepared. The Au oxide films were formed on an Au wire (i.d.: $0.3 \mathrm{~mm}$; length: $20 \mathrm{~mm}$ ) by potential scans between 0.0 and $2.0-3.0 \mathrm{~V}$ ( 5 scans; scan rate: $10-100 \mathrm{mV} / \mathrm{s}$ ) in $10 \mathrm{~mL}$ of a $0.1-1.0 \mathrm{M} \mathrm{NaOH}$ aqueous solution. The scan number for produced Au oxide was optimized in the range of 4-5 cycles, and the selected scan rate was $25 \mathrm{mV} / \mathrm{s}$.

\subsubsection{Voltammetric measurements}

The two voltammetric techniques, cyclic and differential pulse voltammetric voltammetry, were all done on $\mathrm{Au}$ oxide and $\mathrm{Au}$ electrodes, respectively. Voltammograms of heterocycles thiazole were taken on an Au oxide electrode in an acetate buffer ( $\mathrm{pH} 4.90)$, 
<smiles>O=C1CSC(=S)N1</smiles>

Rhodanine

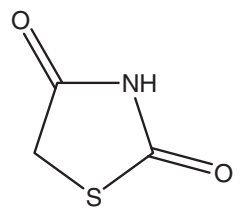

Thiazolidine-2, 4-dione<smiles>C1CSCN1</smiles>

Thiazolidine<smiles>O=C(O)[C@@H]1CSCN1</smiles>

L (-)-Thiazolidine-4-carboxylic acid

Scheme 1. Structure of rhodanine, thiazolidine-2,4-dione, thiazolidine, and L(-)-thiazolidine-4-carboxylic acid.

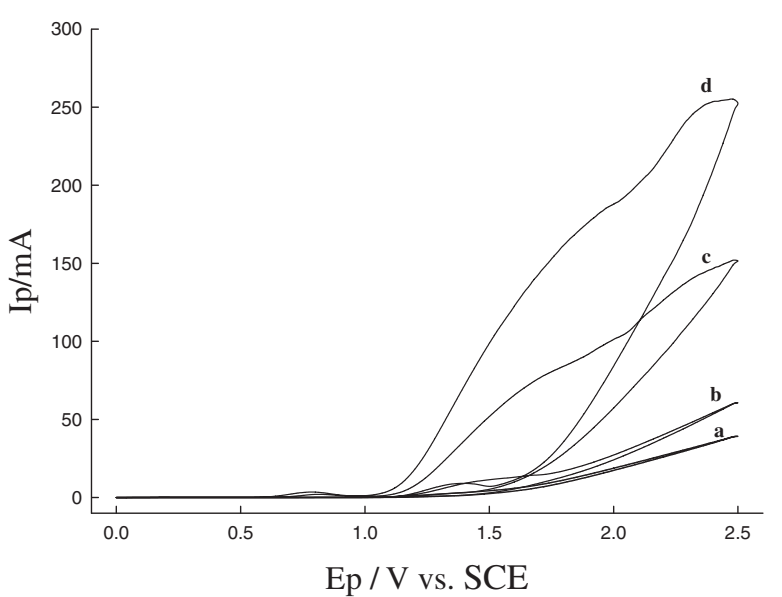

Figure 1. Effect of $\mathrm{NaOH}$ concentration on the electrosynthesis of Au oxide film at a scan rate of $25 \mathrm{mV}$ and on the fifth scan (a) $0.1 \mathrm{M}$; (b) $0.2 \mathrm{M}$; (c) $0.5 \mathrm{M}$; (d) $1.0 \mathrm{M} \mathrm{NaOH}$. Substrate: $3 \mathrm{~mm}$ of $\mathrm{Au}$.

phosphate buffer solutions (pH 2.21), and in Britton and Robinson buffer solutions ( $\mathrm{pH}$ 2.06-6.71).

\section{Results and Discussion}

\subsection{Optimization condition for the formation Au oxide films}

Figure 1 shows the effect of the $\mathrm{NaOH}$ concentration for the electro-synthesis of $\mathrm{Au}$ oxide film at a scan rate $25 \mathrm{mV}$ and on the fifth scan. We found that an elevated reaction concentration of $\mathrm{NaOH}$ was necessary to form $\mathrm{Au}$ oxide films. The peak height (current) increased with the concentration of $\mathrm{NaOH}$ (Fig. 1). The peak current (charge density) in $1 \mathrm{M} \mathrm{NaOH}$ was higher than that in $0.1 \mathrm{M} \mathrm{NaOH}\left(15.5\right.$ vs. $\left.1.61 \mathrm{mC} / \mathrm{cm}^{2}\right)$. An elevated reaction

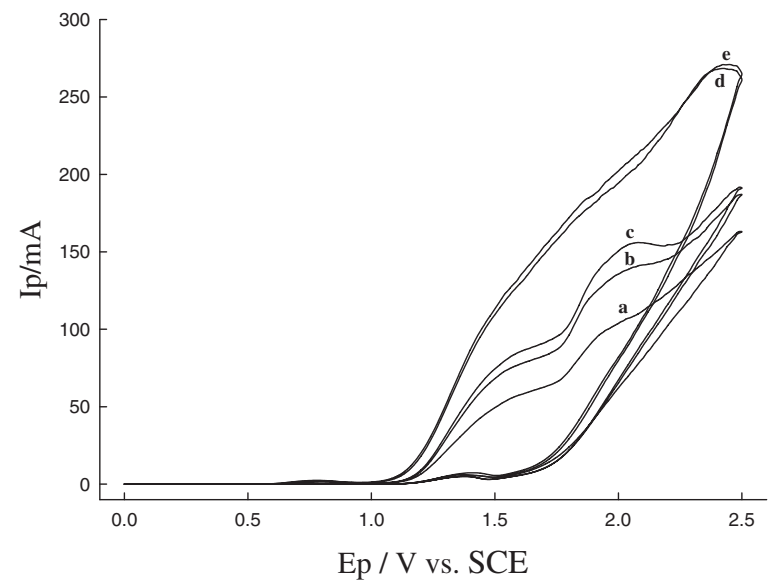

Figure 2. Effect of scan order on the electrosynthesis of Au oxide film in $1.0 \mathrm{M} \mathrm{NaOH}$ solution at a scan rate of $25 \mathrm{mV} / \mathrm{s}$. (a) first scan; (b) second scan; (c) third scan; (d) fourth scan; (e) fifth scan. Substrate: $3 \mathrm{~mm}$ of Au.
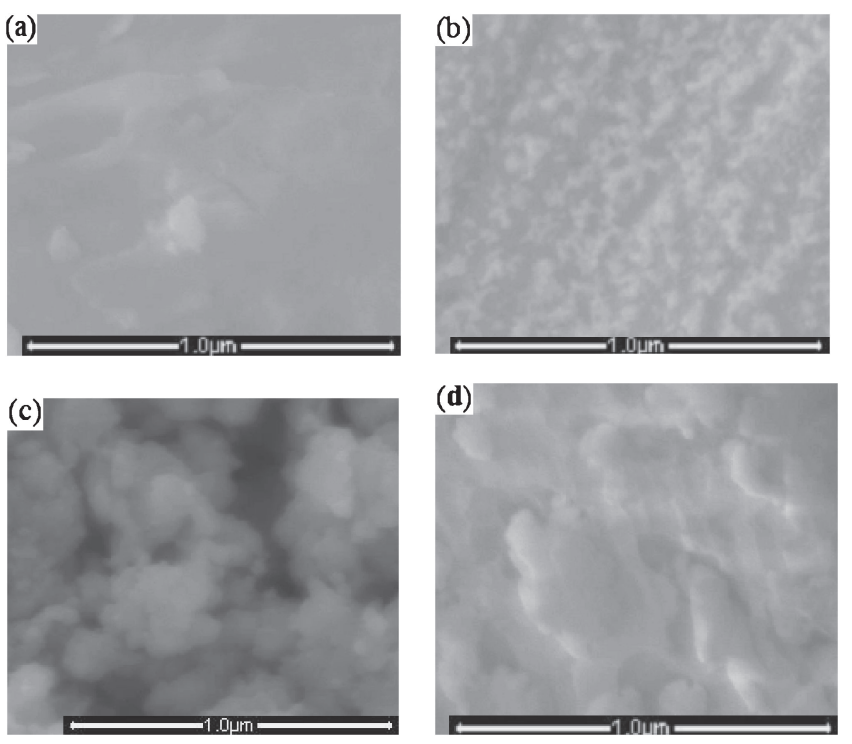

Figure 3. Scanning electron micrographs of $\mathrm{Au}$ oxide films prepared using electrochemically oxidized gold wire $(0.3 \mathrm{~mm})$ in $1.0 \mathrm{M} \mathrm{NaOH}$ solution under cyclic voltammetric potential conditions: (a) between 0 and $1.5 \mathrm{~V}$; (b) between 0 and $2.0 \mathrm{~V}$; (c) between 0 and $2.5 \mathrm{~V}$; (d) between 0 and $3.0 \mathrm{~V}$ at $25 \mathrm{mV} / \mathrm{s}$. Magnification: $50,000 \times$.

concentration like this should be helpful for accelerating the formation rate of $\mathrm{Au}$ oxide films. The effect of scan order (from first to fifth scan) for the electrosynthesis of Au oxide film in $1.0 \mathrm{M}$ $\mathrm{NaOH}$ solution at a scan rate $25 \mathrm{mV} / \mathrm{s}$ is shown in Fig. 2. It is also notable that the peak current increased with the scan number, and that the current difference from the first to the third scan was larger than that from the fourth to the fifth. The scans beyond the fifth scan have small current differences. The scan number of the charge density was calculated to be 3.41 and $12.1 \mathrm{mC} / \mathrm{cm}^{2}$ from the first and fifth scans, respectively. A thin layer of Au oxide was produced on the surface of the $\mathrm{Au}$ electrode. To compare potential conditions $(0-1.5,0-2.0,0-2.5$, and $0-3.0 \mathrm{~V})$, pictures of the four electrodes were taken using a scanning electron microscope (SEM) (JXA-840; JEOL Co., Tokyo, Japan) (Fig. 3). There was no significant change in the morphology of Au oxide particles [Fig. 3(a)]; a number of $\mathrm{Au}$ oxide particles with a diameter of $83-190 \mathrm{~nm}$ aggregated and became much larger throughout the Au substrate [Fig. 3(c)]. The Au 


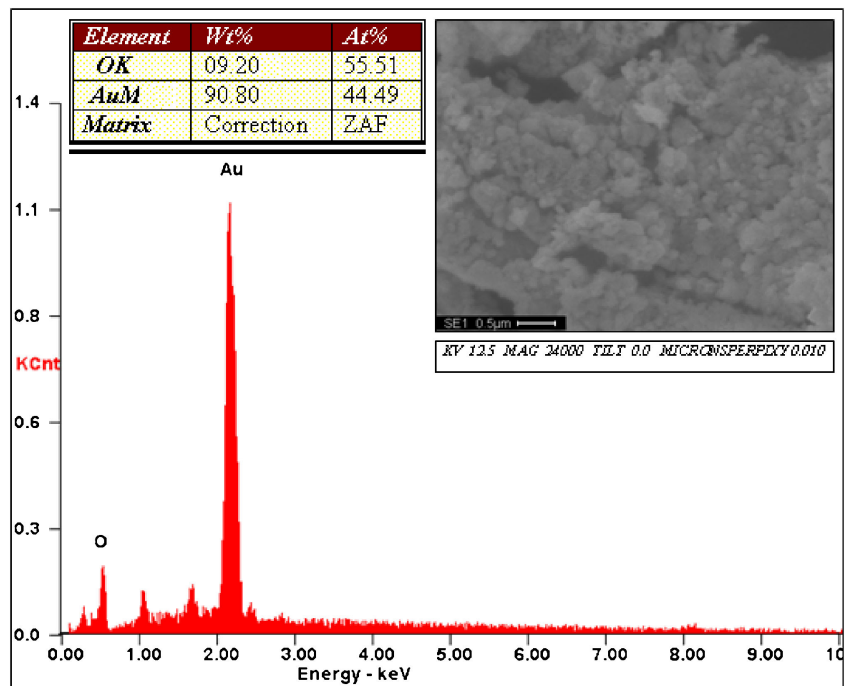

Figure 4. (Color online) Energy dispersion spectroscopy (EDS) of homemade $\mathrm{Au}$ oxide films in $1.0 \mathrm{M} \mathrm{NaOH}$ solution under cyclic voltammetric potential between 0 and $2.5 \mathrm{~V}$ at $25 \mathrm{mV} / \mathrm{s}$.

oxide particles were distributed more uniformly when aggregated on the gold electrode [Fig. 3(c)] than on the other three [Figs. 3(a), 3(b), and 3(d)]. Energy dispersion spectroscopy (EDS) is an analytical technique used for the elemental analysis or chemical characterization of a sample. In the scanning mode, SEM/EDS instruments can be used to produce maps of element location, concentration, and distribution. Figure 4 shows a SEM image as well as the EDS pattern of Au oxide. The EDS spectrum is portrayed as a plot of X-ray counts vs. energy (in $\mathrm{keV}$ ). Two energy peaks of the AuM (At\%: 44.49) and OK (At\%: 55.51) elements appeared in the $\mathrm{Au}$ oxide.

\subsection{Electrochemical behavior of heterocycles thiazole on the Au oxide electrode}

The cyclic voltammogram of rhodanine shows the irreversibility of the process. A single, anodic peak is obtained, and the cathodic peak observed in the reverse scan is due to the reduction of the $\mathrm{Au}$ oxide. Cyclic voltammograms from a $138-\mu \mathrm{g} \mathrm{mL}^{-1}$ rhodanine solution recorded at $\mathrm{Au}$ oxide and $\mathrm{Au}$ electrodes in phosphate buffer ( $\mathrm{pH} 2.21$ ) show that one well-defined oxidation peak appeared at the $\mathrm{Au}$ oxide electrode at $+0.875 \mathrm{~V}$ and that one appeared at the $\mathrm{Au}$ electrode at $+0.981 \mathrm{~V}$ (Fig. 5). The potential was lower and the current higher at the $\mathrm{Au}$ oxide electrode than at the $\mathrm{Au}$ electrode. We found that the $\mathrm{Au}$ oxide electrode performed better than did the $\mathrm{Au}$; therefore, we chose the $\mathrm{Au}$ oxide electrode to determine heterocycles thiazole using differential pulse voltammograms in phosphate buffer ( $\mathrm{pH}$ 2.21) (Fig. 6). There is an electronrich thiazolidine-2,4-dione (peak at $0.387 \mathrm{~V}$ ) backbone because of its two oxygen-molecule-containing group in the five-membered ring structure; the potential of this compound is less positive than that of other heterocycles thiazole.

Table 1 summarizes data obtained from differential pulse voltammetric studies of $4.0 \mu \mathrm{g} \mathrm{mL}^{-1}$ of heterocycles thiazole solution in various other solutions. Our analyses of the effect of $\mathrm{pH}$ and supporting electrolytes on the oxidation peak current and peak potential of heterocycles thiazole in Britton-Robinson buffered solution in the $\mathrm{pH}$ range of 2.06-6.71, phosphate buffer ( $\mathrm{pH}$ 6.62), and acetate buffer ( $\mathrm{pH} 4.90)$ showed that peaks shifted more to positive potential in phosphate buffer $(\mathrm{pH} 2.21)$ and that the peak current in phosphate buffer was higher than in the others (Fig. 7). This indicates that the oxidation of heterocycles thiazole is strongly pH-dependent.

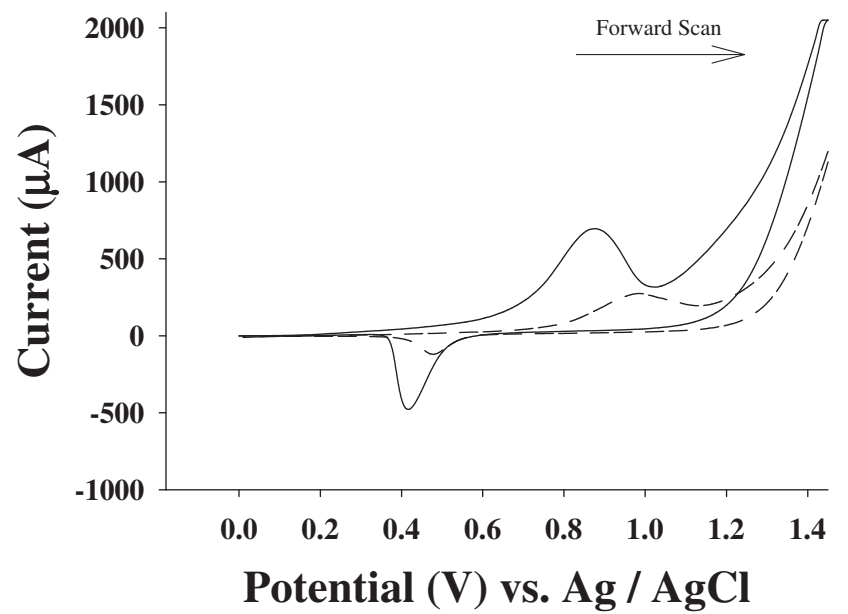

Figure 5. Cyclic voltammograms of rhodanine $\left(138 \mu \mathrm{g} \mathrm{mL}^{-1}\right)$ in phosphate buffer ( $\mathrm{pH} 2.21$ ). The solid line (-) is for an $\mathrm{Au}$ oxide electrode (peak at $0.875 \mathrm{~V}, 694 \mu \mathrm{A}$ ); the dashed line (---) is for an $\mathrm{Au}$ electrode (peak at $0.981 \mathrm{~V}, 268 \mu \mathrm{A}$ ).

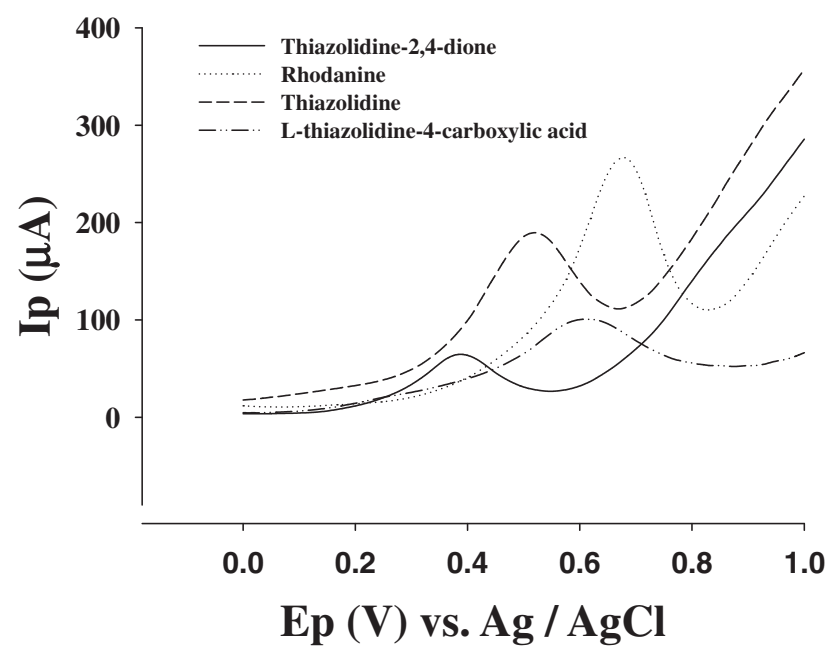

Figure 6. Differential pulse voltammograms of five-membered heterocyclic compounds (nitrogen, sulfur) $\left(60 \mu \mathrm{g} \mathrm{mL}^{-1}\right)$ in phosphate buffer ( $\mathrm{pH} 2.21)$. The solid line is for a thiazolidine-2,4-dione (peak at $0.387 \mathrm{~V}, 64.6 \mu \mathrm{A}$ ); the dotted line is for a rhodanine (peak at $0.676 \mathrm{~V}, 264 \mu \mathrm{A})$; the medium dashed line is for a thiazoline peak at $(0.515 \mathrm{~V}, 190 \mu \mathrm{A})$; the dash-dot-dot $(-.$.$) line is for an L-thiazoline-$ 4-carboxylic acid (peak at $0.613 \mathrm{~V}, 99.4 \mu \mathrm{A}$ ).

\subsection{Catalysis of the oxidation of rhodanine by the Au oxide electrode}

Cyclic voltammograms were obtained using the standard addition method at the $\mathrm{Au}$ oxide electrode (Fig. 8) (regression equation: $y=3.26 x-53$; correlation coefficient: $\mathrm{r}=0.9976$ ). The oxidative peak current increases linearly with the concentration of rhodanine, which indicates that the process is diffusion-controlled. The linear relationship found for low concentrations $\left(5-140 \mu \mathrm{g} / \mathrm{mL}^{-1}\right)$ offers notable advantages in the analysis of small amounts of rhodanine in aqueous solution. Cyclic voltammograms were recorded at different scan rates (Fig. 9). The effect of the scan rate $(5-800 \mathrm{mV} / \mathrm{s})$ on the electro-oxidation of rhodanine was examined in aqueous methanol. There was good linearity between the peak height (current) and the square root of the scan rate [Fig. 10(A)]. The relationship between peak potential and the logarithm of the scan rate [Fig. 10(B)] can be used to roughly estimate the number of electrons involved in the catalytic oxidation. For a totally irreversible electrochemical 
Table 1. Effect of $\mathrm{pH}$ and supporting electrolytes on the differential pulse voltammetric peak potential and peak current of thiazole heterocycles at $\mathrm{Au}$ oxide and $\mathrm{Au}$ electrodes.

\begin{tabular}{|c|c|c|c|c|c|c|c|c|c|c|c|c|c|c|c|c|}
\hline \multirow{5}{*}{$\begin{array}{c}\text { Analytes } \\
4.0\left(\mu \mathrm{g} \mathrm{mL}^{-1}\right)\end{array}$} & \multicolumn{6}{|c|}{ Phosphate buffer } & \multirow{2}{*}{\multicolumn{2}{|c|}{$\begin{array}{l}\text { Acetate buffer } \\
\mathrm{pH} 4.90\end{array}$}} & \multicolumn{8}{|c|}{ Britton-Robison buffer } \\
\hline & \multicolumn{2}{|c|}{ pH 2.21} & \multicolumn{2}{|c|}{$\mathrm{pH} 2.21$} & \multicolumn{2}{|c|}{$\mathrm{pH} 6.62$} & & & \multicolumn{2}{|c|}{ pH 2.06} & \multicolumn{2}{|c|}{$\mathrm{pH} 4.68$} & \multicolumn{2}{|c|}{$\mathrm{pH} 5.42$} & \multicolumn{2}{|c|}{ pH 6.71} \\
\hline & \multicolumn{8}{|c|}{ Peak potential $(\mathrm{V})$; Current $(\mu \mathrm{A})$} & \multirow{2}{*}{\multicolumn{8}{|c|}{$\begin{array}{c}\text { Peak potential }(\mathrm{V}) \text {; Current }(\mu \mathrm{A}) \\
\mathrm{Au} \text { oxide }\end{array}$}} \\
\hline & $\mathrm{Au}$ (i.d.: & $3 \mathrm{~mm})$ & $\mathrm{Au}$ & xide & $\mathrm{Au}$ & xide & $\mathrm{Au}$ & xide & & & & & & & & \\
\hline & (V) & $(\mu \mathrm{A})$ & $(\mathrm{V})$ & $(\mu \mathrm{A})$ & $(\mathrm{V})$ & $(\mu \mathrm{A})$ & (V) & $(\mu \mathrm{A})$ & $(\mathrm{V})$ & $(\mu \mathrm{A})$ & $(\mathrm{V})$ & $(\mu \mathrm{A})$ & $(\mathrm{V})$ & $(\mu \mathrm{A})$ & $(\mathrm{V})$ & $(\mu \mathrm{A})$ \\
\hline Rhodanine & 1.03 & 29.8 & 0.54 & 205 & 0.49 & 47.7 & 0.60 & 97.1 & 0.51 & 43.0 & 0.53 & 36.3 & 0.51 & 47.6 & 0.50 & 46.3 \\
\hline Thiazolidine-2,4-dione & 1.00 & 18.5 & 0.40 & 62.8 & 0.42 & 26.6 & 0.55 & 63.6 & 0.47 & 31.5 & 0.44 & 31.0 & 0.48 & 36.7 & 0.48 & 39.7 \\
\hline Thiazolidine & 1.14 & 9.27 & 0.47 & 141 & 0.55 & 41.8 & 0.67 & 135 & 0.45 & 25.9 & 0.50 & 34.7 & 0.56 & 41.7 & 0.55 & 49.1 \\
\hline $\begin{array}{l}\mathrm{L}(-) \text {-Thiazolidine- } \\
\text { 4-carboxylic acid }\end{array}$ & 0.86 & 15.1 & 0.48 & 79.4 & 0.52 & 31.6 & 0.36 & 54.6 & 0.57 & 40.3 & 0.54 & 27.9 & 0.52 & 37.2 & 0.52 & 23.9 \\
\hline
\end{tabular}

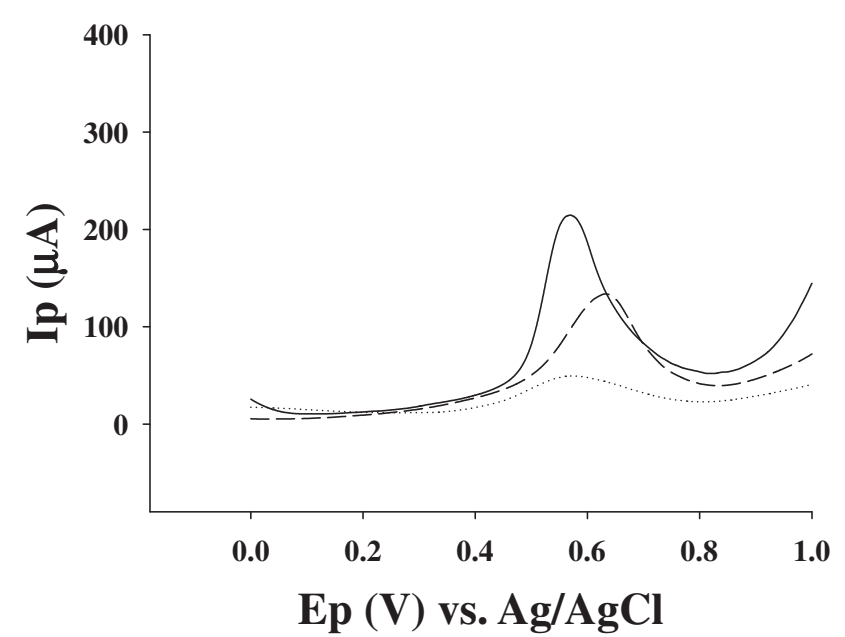

Figure 7. Differential pulse voltammograms of rhodanine $\left(8 \mu \mathrm{g} \mathrm{mL}^{-1}\right)$ in various electrolytes at an $\mathrm{Au}$ oxide electrode. The solid line $(-)$ is phosphate buffer $(\mathrm{pH} 2.21)$ (peak at $0.567 \mathrm{~V}$, $212 \mu \mathrm{A})$; the medium dashed line (---) is acetate buffer (pH 4.90) (peak at $0.630 \mathrm{~V}, 133 \mu \mathrm{A}$ ); the dotted line $(\cdots)$ is Britton-Robison buffer (pH 5.42) (peak at $0.571 \mathrm{~V}, 49.8 \mu \mathrm{A})$.

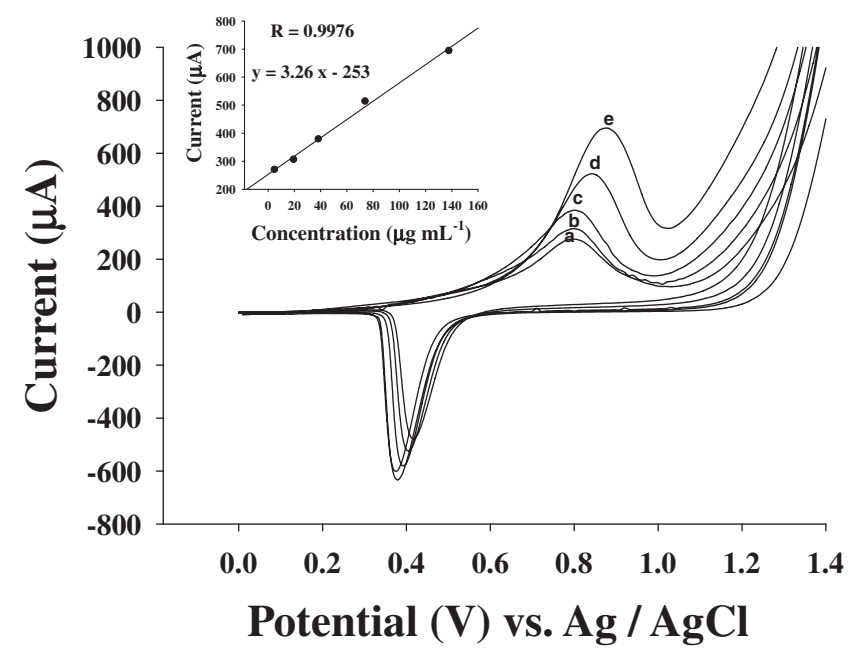

Figure 8. Cyclic voltammograms of rhodanine in different concentrations at an $\mathrm{Au}$ oxide electrode and a related currentconcentration curve: (a) $5 \mu \mathrm{g} \mathrm{mL}^{-1}(0.799 \mathrm{~V}, 270 \mu \mathrm{A})$; (b) 20 $\mu \mathrm{g} \mathrm{mL}^{-1}(0.799 \mathrm{~V}, 306 \mu \mathrm{A})$; (c) $40 \mu \mathrm{g} \mathrm{mL}^{-1}(0.804 \mathrm{~V}, 379 \mu \mathrm{A})$; (d) $80 \mu \mathrm{g} \mathrm{mL}^{-1}(0.839 \mathrm{~V}, 514 \mu \mathrm{A})$; (e) $140 \mu \mathrm{g} \mathrm{mL}^{-1}(0.875 \mathrm{~V}, 694 \mu \mathrm{A})$; in phosphate buffer solution at a scan rate of $25 \mathrm{mV} / \mathrm{s}$.

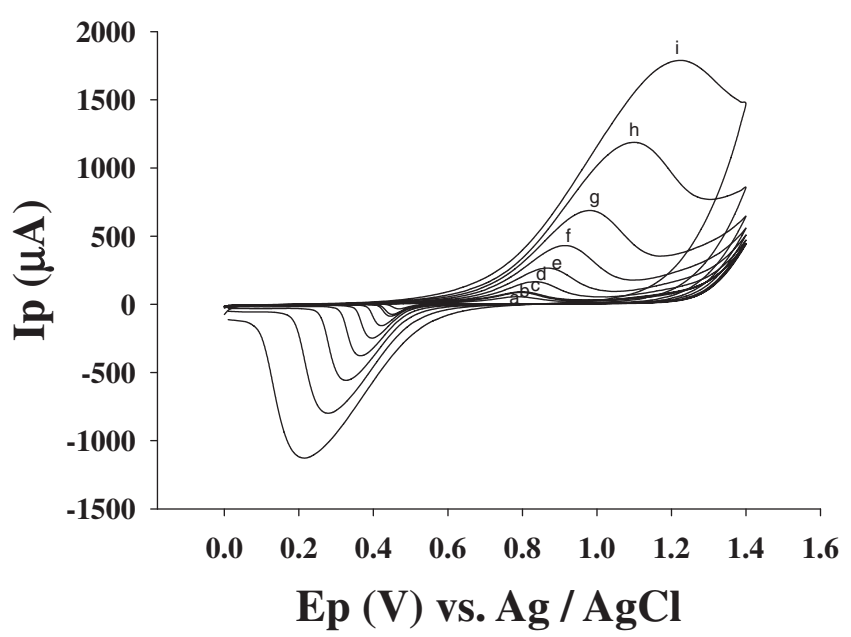

Figure 9. Cyclic voltammograms of rhodanine $\left(48 \mu \mathrm{g} \mathrm{mL}^{-1}\right)$ in phosphate buffer ( $\mathrm{pH} 2.21$ ) on Au oxide electrode at different scan rates: (a) $5 \mathrm{mV} / \mathrm{s}(0.786 \mathrm{~V}, 56.1 \mu \mathrm{A})$; (b) $10 \mathrm{mV} / \mathrm{s}(0.799 \mathrm{~V}, 86.0$ $\mu \mathrm{A}) ;$ (c) $12.5 \mathrm{mV} / \mathrm{s}(0.802 \mathrm{~V}, 91.3 \mu \mathrm{A}) ;$ (d) $25 \mathrm{mV} / \mathrm{s}(0.833 \mathrm{~V}$, $166 \mu \mathrm{A})$; (e) $50 \mathrm{mV} / \mathrm{s}(0.868 \mathrm{~V}, 265 \mu \mathrm{A})$; (f) $100 \mathrm{mV} / \mathrm{s}(0.912 \mathrm{~V}$, $429 \mu \mathrm{A}) ;(\mathrm{g}) 200 \mathrm{mV} / \mathrm{s}(0.983 \mathrm{~V}, 690 \mu \mathrm{A})$; (h) $400 \mathrm{mV} / \mathrm{s}(1.10 \mathrm{~V}$, $1191 \mu \mathrm{A})$; (i) $800 \mathrm{mV} / \mathrm{s}(1.21 \mathrm{~V}, 1789 \mu \mathrm{A})$.

oxidation, the peak current in cyclic voltammograms can be expressed as:

$$
\mathrm{I}_{\mathrm{p}}=\left(2.99 \times 10^{5}\right) \mathrm{n}\left(\alpha \mathrm{n}_{\mathrm{a}}\right)^{1 / 2} \mathrm{AC}_{0} \mathrm{D}_{0}{ }^{1 / 2} v^{1 / 2}
$$

where $I_{p}$ is the peak current, $n$ is the number of electrons involved in the oxidation, $\alpha \mathrm{n}_{\mathrm{a}}$ is a parameter reflecting the irreversibility of the oxidation, $\mathrm{A}$ is the area of the electrode $\left(\mathrm{cm}^{2}\right), \mathrm{C}_{0}$ is the concentration of substrate, $v$ is the potential scan rate, and $\mathrm{D}_{0}$ is the diffusion coefficient of the substrate. The value of $\mathrm{n}\left(\alpha \mathrm{n}_{\mathrm{a}}\right)$ can be calculated from the slope of the line shown in Fig. 10A: $n_{a}=0.8$ (approximately) for an irreversible process. On the other hand, the peak potential in cyclic voltammograms can be expressed as a function of the logarithm of the scan rate: $E_{p}=$ constant $+2.3 \mathrm{RT} /$ $2 \alpha \mathrm{n}_{\mathrm{a}} \mathrm{F} \log v$; it can be used to roughly estimate the number of electrons involved in the catalytic oxidation. The controlledpotential coulometry was done in buffered solution (phosphate: $\mathrm{pH} 2.21$ ) containing $6.45 \times 10^{-4} \mathrm{M}$ rhodanine at the constant anodic potentials of 1.0 and $1.5 \mathrm{~V}$ (vs. $\mathrm{Ag} / \mathrm{AgCl}$ ). The progression of the electrolysis process, monitored using cyclic voltammetry, shows that the peak current for rhodanine $(1.37 \mathrm{~V})$ decreased and that the peak current for the newly appeared anodic wave $(1.09 \mathrm{~V})$ in less-positive potential increased. Rhodanine and the electrolyzed 

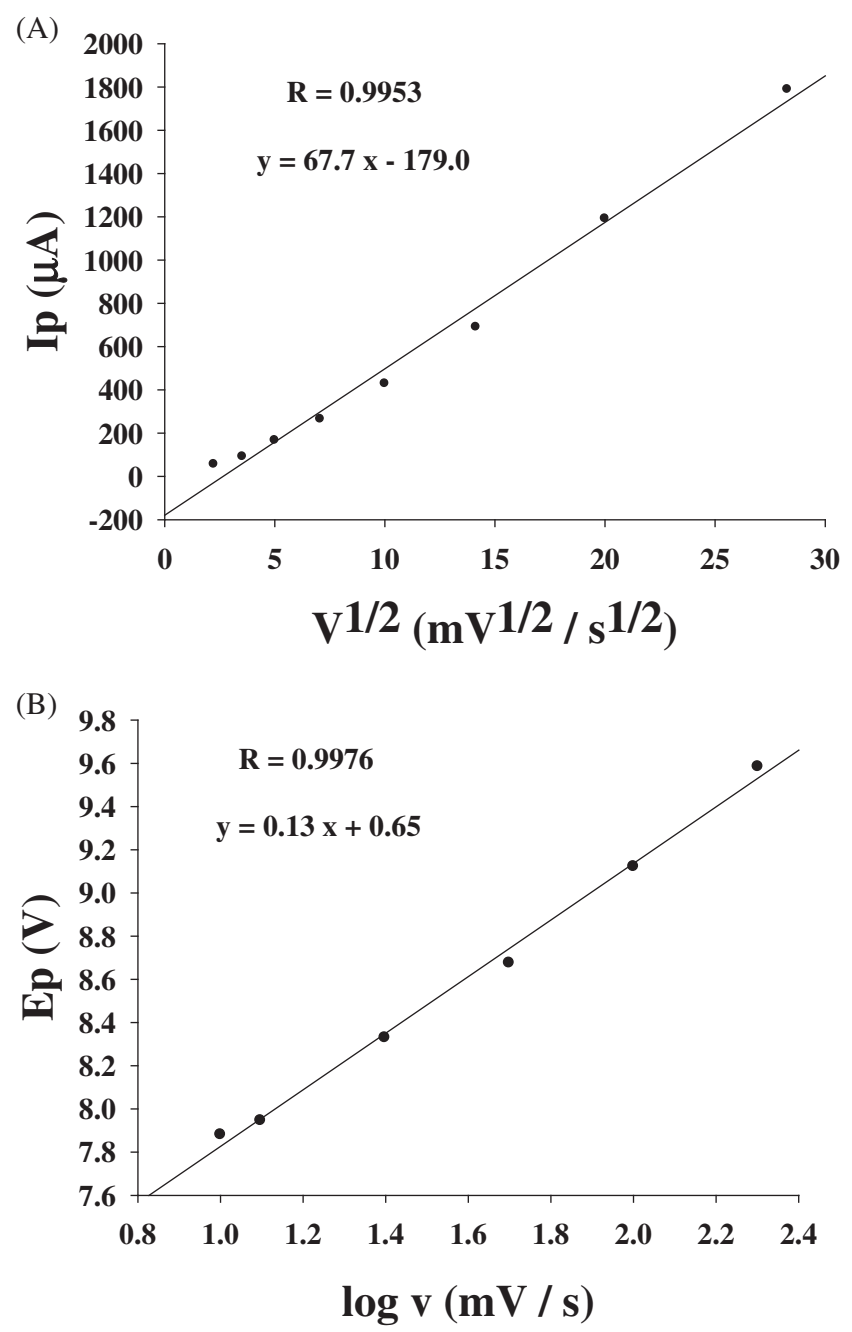

Figure 10. (A) Magnitude of the peak current, Ip, for rhodanine oxidation as a function of the square root of the scan rate and (B) peak potentials.

solution (sulfoxides) were analyzed using gas chromatography (GC) (GC-2014 with FID (flame ionization detection); Shimadzu Taiwan Industrial Machinery, Hsinchu City, Taiwan) and an HP-5 column $(60 \mathrm{~m} \times 0.32 \mathrm{~mm}$; film thickness: $0.25 \mu \mathrm{m})$ (Agilent Technologies, Santa Clara, CA) and GC/MS (gas chromatography/mass spectrometry) (QP-2010 mass spectrometer; Shimadzu Taiwan) and a
DB-5 (5\% phenyl-methylpolysiloxane) fused silica capillary column $(30 \mathrm{~m} \times 0.25 \mathrm{~mm}$, film thickness $0.25 \mu \mathrm{m})$. Because rhodanine is thermally unstable, it does not yield stable chromatograms: it has no boiling point and easily decomposes at temperatures $>171{ }^{\circ} \mathrm{C}$. Therefore, high-performance liquid chromatography (HPLC) and Fourier transform infrared (FT-IR) spectrophotometry were used to characterize the products of the oxidation process in the electrolyzed solution for rhodanine. The electrolyzed solution was extracted with ethyl acetate:hexane $(3: 2, \mathrm{v} / \mathrm{v})$ and then concentrated for HPLC and FT-IR analysis. Elution and HPLC analysis of the electrolyzed solution were done using a Luna $\mathrm{C}_{18}$ column $(250 \mathrm{~mm} \times 4.6 \mathrm{~mm})$ (Phenomenex, Torrance, CA) during the mobile phase with methanol-phosphate buffer ratios $(10: 90, v / v)$ containing $1.0 \mathrm{mM}$ dihydrogen potassium phosphate $(\mathrm{pH} 6.85)$ at a flow rate of $1 \mathrm{~mL} / \mathrm{min}$, and at a detection wavelength of $290 \mathrm{~nm}$. The retention time of the new peak was $7.63 \mathrm{~min}$ and of rhodanine was $8.51 \mathrm{~min}$. The sulfoxide group $(\mathrm{S}=\mathrm{O})$ stretching frequency is usually at 1070 $1030 \mathrm{~cm}^{-1}$. The IR spectra of electrolyzed residue in $\mathrm{KBr}$ had an $\mathrm{S}=\mathrm{O}$ stretching bond at $\sim 1074 \mathrm{~cm}^{-1}$ and an N-H rocking band at $682 \mathrm{~cm}^{-1}$. The total number of electrons was determined using controlled-potential coulometry with a gold electrode. The accumulated charge $(\mathrm{Q})$ was taken from the digital coulometer at a curve (potential corresponding to peak current) of the oxidation wave. Applying the equation:

$$
\mathrm{Q}=\mathrm{nFw} / \mathrm{M}
$$

where $\mathrm{w}$ is the weight of the sample in grams and $\mathrm{M}$ its molecular weight, the value of $\mathrm{n}$ for rhodanine was two electrons. The anodic oxidation of organic sulfides in the presence of water clearly proceeds by successive two-electron steps to afford sulfoxides and sulfones. ${ }^{28,29}$ Therefore, a possible mechanism is given in Scheme 2.

\section{Conclusions}

$\mathrm{Au}$ oxide film on Au electrode and its supported Au catalysts was fabricated using potentiostatic and potential cycling conditions. The present work shows that the anodic oxidation of heterocycles thiazole on an $\mathrm{Au}$ oxide electrode in the $\mathrm{pH}$ range 2.06-6.71 was investigated. The presented DPV method is simple and can be directly used for precisely and accurately monitoring sub-micromolar amounts of the heterocycles thiazole in aqueous buffered solutions.

\section{Acknowledgments}

This work was financially supported by grant National Science Council of the Republic of China (NSC 99-2113-M-041-001-MY3).
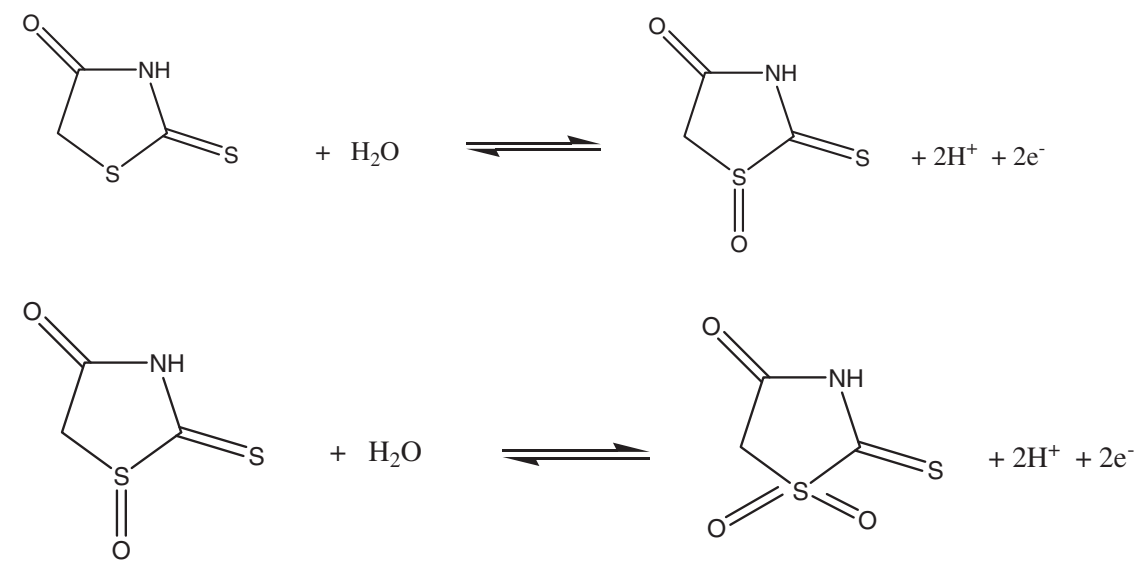

Scheme 2. Possible mechanism. 


\section{References}

1. T. Tomasic, K. Tihomir, S. Andreja, B. Mihael, G. Didier, G. Simona, S. Gobec, D. Kikelj, and P. M. Lucija, Eur. J. Med. Chem., 46, 3964 (2011).

2. J. H. Ahn, S. J. Kim, P. Jun, W. S. Park, S. Y. Cho, J. D. Ha, S. S. Kim, S. K. Kang, D. G. Jeong, S. K. Jung, and S. H. Lee, Bioorg. Med. Chem. Lett., 16, 2996 (2006).

3. L. V. Sonawane and S. B. Bari, Latin Am. J. Pharm., 30, 568 (2011)

4. T. Tomasic and L. P. Masic, Curr. Med. Chem., 16, 1596 (2009).

5. T. Haripriya, G. Ramakant, and V. S. Velingkar, Indian J. Heterocycl. Chem., 14, 75 (2004).

6. M. Pfahl, C. Tachdjian, L. W. Spruce, H. A. Al-Shamma, M. Boudjelal, A. N. Fanjul, T. R. Wiemann, and D. P. M. Pleynet, PCT Int. Appl., WO 2003043998 A1 20030530 (2003)

7. C. D. Barros, A. A. Amato, T. B. de Oliveira, K. B. Rocha Iannini, A. Lauro da Silva, T. Gonçalves da Silva, E. Soares Leite, M. Zaldini Hernandes, M. do Carmo Alves de Lima, S. Lins Galdino, A. Rocha Neves F de, and I. da Rocha Pitta, Bioorg. Med. Chem., 18, 3805 (2010).

8. A. Rodrigues e Silva, A. J. da Silva Góes, W. Tavares de Lima, and M. B. de Souza Maia, Chem. Pharm. Bull., 51, 1351 (2003).

9. M. S. A. El-Gaby, A. El-Hag, A. M. Gameel, A. A. El-Maghraby, M. T. El-Rahman, T. Mohamed, and M. H. M. Helal, Eur. J. Med. Chem., 44, 4148 (2009).

10. V. Kshirsagar, S. Gandhe, and M. D. Gautam, Asian J. Chem., 20, 4955 (2008).

11. S. Rajinder, R. Usha, J. Clough, S. D. Issakani, and G. C. Look, PCT Int. Appl., WO 2005041951 A2 20050512 (2005).

12. V. Kshirsagar, S. Gandhe, and M. D. Gautam, Rasayan J. Chem., 3, 772 (2010)
13. S. Gandhe, A. Pradhan, and M. D. Gautam, J. Indian Chem. Soc., 80, 143 (2003).

14. P. L. Breuer, C. A. Sutcliffe, and R. L. Meakin, Hydrometallurgy, 106, 135 (2011).

15. A. T. Mubarak, A. Z. El-Sonbati, and A. A. El-Bindary, Chem. Pap., 58, 320 (2004).

16. A. Noorbakhsh and A. Salimi, Electrochim. Acta, 54, 6312 (2009).

17. G. M. Veith, A. R. Lupini, S. T. Pennycook, and N. J. Dudney, ChemCatChem, 2 , 281 (2010).

18. Y. Zhang, J. Deng, L. Zhang, W. Qiu, H. Dai, and H. He, Catal. Today, 139, 29 (2008).

19. P. I. Iotov and S. V. Kalcheva, Gold Bull., 34, 95 (2001).

20. S. J. Xia and V. I. Birss, Proc. Electrochem. Soc., 2003, 25 (2004).

21. S. J. Xia and V. I. Birss, J. Electroanal. Chem., 500, 562 (2001).

22. A. C. García and P. Blanco, J. Electroanal. Chem. Interfacial Electrochem., 245, 157 (1988).

23. Z. J. Karpinski and J. Radomski, Anal. Lett., 22, 2291 (1989).

24. Z. J. Karpinski, M. Karny, and Z. Kublik, J. Electroanal. Chem. Interfacial Electrochem., 288, 129 (1990).

25. H. M. Fahmy, M. Abdul-Wahab, and H. Abdel-Reheem, J. Electroanal. Chem. Interfacial Electrochem., 184, 135 (1985).

26. M. T. Mohamed, E. M. Mabrouk, and E. H. El-Mossalamy, Mat. Sci. Res. India, 3, 155 (2006).

27. P. Singh, P. Kumar, A. Katyal, R. Kalra, S. K. Dass, S. Prakash, and R. Chandra, Spectrochim. Acta Part A: Mol. Biomol. Spectrosc., 75, 983 (2010).

28. J. M. Fernandez Alvarez, A. Costa García, A. J. Miranda Ordieres, and P. Tuñon Blanco, J. Electroanal. Chem. Interfacial Electrochem., 209, 241 (1986).

29. D. Kyriacou, Modern Electroorganic Chemistry, Springer-Verlag, Berlin, Heidelberg, p. 74 (1994). 